\title{
Sustainable Resin Collection and trade Practices in Mid Hills of Nepal
}

\author{
Bharat Gotame ${ }^{1}$ \\ Email: bgotame@gmail.com
}

\begin{abstract}
Non Timber Forest Products (NTFPs) in mountains are one of the enormously valued ecosystem services due to their contribution to the livelihood of people. Pine resin is one of the viable NTFP in middle mountain of Nepal which is tapped from Pinus roxbhurghii tree and can be used in paints, varnishes, stimulant, anti-spasmodic, astringent, diuretic and anti-pathogenic and so on. This piece of work is an attempt to review the current status of pine resin collection enterprise in Nepalese Community Forests and its contribution to the livelihood of Community forest users in mid-hill region. Typically, existing legislations and guidelines have high potential to endure the sustainable livelihood promotion by resin tapping enterprise but the endeavors of revitalizing the financial benefit sharing and governance system is still far. The valued contribution of resin enterprise to sustainable livelihood of users is not impossible but it needs greater effort of all stakeholders. For example, partial intervention to market, involvement of poorer households, improve the local and regional governance and so on. Participatory monitoring of collection work and proper enforcement of sustainable harvesting procedure both have to be improved in state of arts that could finally recognize the rational benefit sharing mechanism among various value chain actors from collector to international traders which is indispensable.
\end{abstract}

Key Words: Resin collection, Pine forest, Sustainability, CFUG, Community Forest

\section{Introduction}

The concentrated interests on NTFPs began in the late 1980s and grew with the emerging concept of sustainable development in early 1990s (Belcher et al., 2005). Basically, the extraction of NTFPs does not have any lethal effect on the natural growth of the plant. If the whole plant is harvested, little caution also can minimize the impact on the life cycle of that plant. So, Myers (1988), Evans (1993) and Plotkin and Famolare (1992) concluded that NTFP harvesting is more benign than timber harvesting and it also can provide incentives for local people (Belcher et al., 2005).

${ }^{1}$ Student, Kathmandu Forestry College 
Following the critical comments on definition of NTFP and its elements of Belcher (2003), it can be defined that Pine resin is non-woody, extractive chemical product from in-situ systems of forest tree conservation in pure natural environment with explicitly harvesting scale either from public or private ownership to large extent of enterprising domain. Pine resin is one of the valuable plant extracts which is popularly tapped from 12 different pine tree species (Coppen \& Hone, 1995) around the world. The principal products of pine resin are rosin and turpentine oil (both could be obtained by distillation of Pine resin) and which are mainly used in paints, varnishes and soap manufacturing. Besidethese some medicinal value can be used in stimulant, anti-spasmodic, astringent, diuretic and anti-pathogenic. Shanley et al (2002) predicted that per year, 128,000 tonnes of resins were being deficit in European continent and the annual prouduction in southern Europe is found sharply decreasing from 1982 to 1997 . Which indicates the demand of resin and also the arguments are being made on promotion of use of biological products (like rosin and turpentine).

In Nepal, 5,856 number of flowering plants are recorded (GoN/MoFSC, 2002), among them 690 species are used as medicinal uses (Shakya \& Malla 1984, adopted from Sharma, 2007). The existing policies are seen promising for conservation, management and utilization of NTFPs (GoN, 2004; GoN, 1995; Sharma. 2007) specifically with the participatory approach in resource conservation. The management of community forests of Nepal has reported that it has a demonstrable contribution to the livelihood of local people, especially for those who has less privately owned resources and NTFPs are seen as major income sources in mid-mountain regions.

NTFP policy development process was progressively adopted with overall conservation policy formation like as forest policy (Edmonds, 2002). A discrete NTFP policy was formulated in 2003 which was instrumental for participatory approach of sustainable harvesting, commercialization of NTFP, certification scheme and promotion of appropriate technologies for cultivation (GoN, 2004).The contribution of NTFPs is incredibly appreciated by local communities as NTFPs play significant role for providing subsistence income to large part of world's population (Pimentel et al. 1997). In Nepal, livelihood of rural people mostly depend on collection and trade of NTFPs (Chhetri et al. 2010) although the collection of pine resin work in Nepal is not found satisfactorily speeding up.

\section{Resin collection in Community managed forest}

Pinus roxburghii has long been tapping in Nepal by evidence of high yielding resin than other pine trees, which is found in elevation of $900-1,500 \mathrm{~m}$ and sometimes upto 2,700 meter from mean sea level (Jackson, 1996) by making a simple cut in surface of live bark in live conditions. The resin is stored in resin canals and are either large longitudinal ducts in wood or small ducts in the aray at right angles to the larger ducts (Mehata, 1981). Although there were practices of resin collection in India in 1896, it emerged in Nepal after the establishment of Laxmi Rosin and Turpentine Industry in 1986. Within these 25 years, the number of resin industries and resin tapping process is growing significantly. Some statistics showed that 40,438 metric ton resin extraction agreement was made between 15 different 
rosin and turpentine companies and government until 2007 and 35 different districts have practices of resin collection (GRTL, 2007 adopted from Subedi, 2010). Rill method of resin tapping is adopted in Nepal which was experimented and believed to be less impacted to forest stand and high extraction.

The success stories of CFUGs and their contribution to the livelihood of rural people and conservation of forest resources are seen viable to forward the financially beneficial pine resin collection work through CFUGs. Some of the EIA/IEE reports of resin companies and summary of trade of resin in Nepal also briefed the potency of enterprising through CFUG. Pinus roxburghii is dominant tree species in mid-hill community forest which was further supplemented by plantation of huge extent in the mid-hills of Nepal during 1970 and 1980 as part of participatory forestry development program (Campbell and Bhattarai, 1983 adopted from Jackson, 1994).

According to Kanel (2004), less than 5\% was the share of NTFPs in overall transaction of goods provided by CF in Nepal, which was due to the huge proportion of timber and fuelwood business. Among the NTFPs, resin has second most contribution to the revenue of CFUG (figure 2) topped by Acacia catechu (raw material of katha). Some eyewitnesses from rosin and turpentine market, forest officials also realized that the quantity of resin tapping is growing highly after the promulgation of government rosin collection guidelines, 2007 and development of consensus over the right of factual use of CF resources in the mid-hill CFUGs. That argument was further supported by the investment of CFUG in community development because most western hill's CFUGs have resin as source of their income.

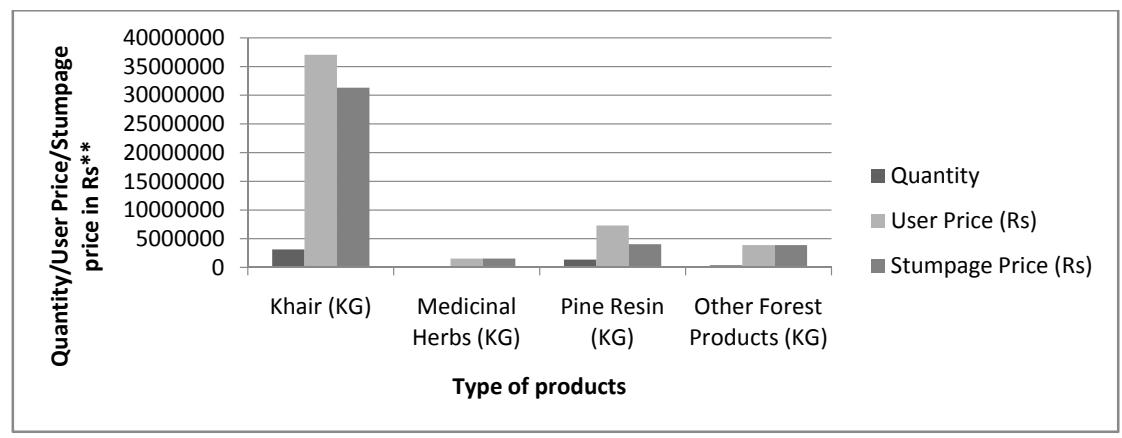

**Rs= Neplese currency and can be count \$1=Rs 75 approximately Data source: Kanel, 2004

Figure 1: NTFP harvested/collected and sold outside CFUG

Likewise, there is increasing trend of resin tapping quantity from the national forest and community forest and revenue to the government also equally mounting since 2005/06 (figure 3).Ridiculous data management system of concerned authorities deserved the cause of lacking effective figures about actual resin collection from CF because almost nil data is available with DoF (Gyawali, 2010) about how much resin has been collected from and how much benefits are obtained by local users in $\mathrm{CF}$ regime. 


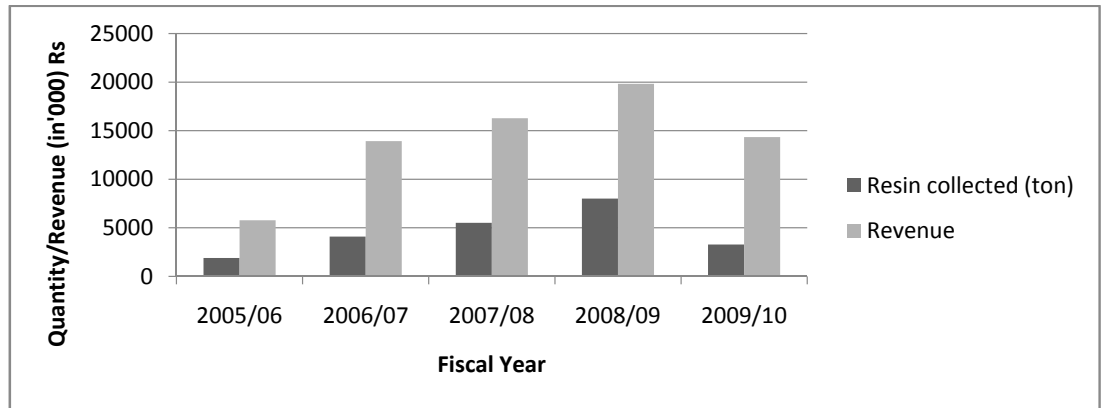

Figure 2: Resin collection data in ton and revenue in Rs (Data Source: DoF, 2010 from Gywanli 2010)

\section{Resin trade}

The distribution of physical assets often gets high importance for benefits to the poor people (Wunder, 2001) for example lack of appropriate market access, most of NTFP collectors lose their large share of benefits due to middle man business people in high and mid mountain regions of Nepal (Chhetri et al, 2010). Some CFUG of Nepal has operated essential oil processing and enables to promote the value of locally cultivating products in motor-able transport districts. The majority of NTFP collectors are compelled to sell their products to the road head traders without having information of demand and supply situation of the market and more than $90 \%$ of NTFP is exported to the India in crude form which hinders the opportunity of value addition. Pine resin collection enterprise found somehow different than other NTFP marketing channels but very few chances of effective value chain mechanism is exist in the case of pine resins as shown in figure 4.

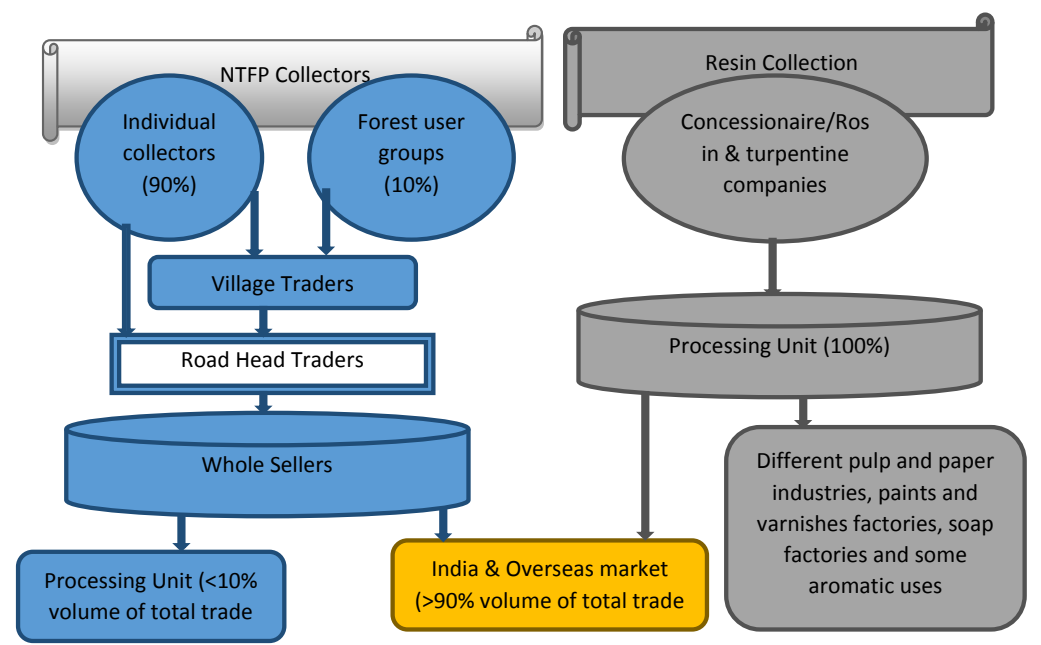

Figure 3: Trade pattern of NTFP andresin 
In summary, Trade and Export Promotion Centre (TEPC: An official body of government of Nepal for export and import statistic) has categorized resin as herbs and exported to India, which was the worth of 580.21 million Nepalese rupees in 2008/09 and sharply decrease in 2009/2010. Considering to the DoF, 2010 and TEPC, 2010, the figures were not seen differently although there might have more limitations to conclude which species/product collection/extraction was decreased or increased.

\section{Sustainability dimensions}

\section{Ecologically favorable}

It was revealed that majority of wild harvesting and extraction of NTFP practices have been facing over harvesting and exploitation problem (Heinen et al., 2006, Ojha, 2000, Nurse et al., 2005). And also perceived that was somehow linked with tenure issue and socio-economic status of people engaged in such events. As stated in resin collection guideline 2007, the regular monitoring of the forest patches en route to monitor the resin tapping process would be cost effective to reduce the illegal harvesting of flora and fauna and decrease the probability of fire incident. It is variously noted that the policy is found more supportive to execute the minimum impact harvesting by EIA or IIE as imposed by Environmental protection act 1995. And more laws, regulations, by-laws and directions are effective to guide the sustainable conservation practices in community forest. For example, the ecological considerations of resin tapping process are addressed by Resin Collection Guideline (RCG, 2007 (See box 1).

Box 1: Highlights of provision made for ecological sustainability in Resin Collection Guideline, 2007

- $\quad$ The pine tree must be of $>30 \mathrm{~cm}$ diameter at breast height (DBH).

- Forest inventory is mandatory for defining annual allowable extraction with special consideration on average crown density closure.

- Prohibit resin extraction on soil-erosion prone areas, high biodiversity areas, and culturally heritage zone.

- $\quad$ Resin collection concessionaire must be carried 5 hector plantation and 5 years of after care if they got 1000 metric ton resin collection permit and in case of more than 1000 metric ton, additional 3.5 ha plantation for each 1000 metric ton.

- In favour of natural regeneration, 5 dominant trees should be left per hector of resin collection forest area and maximum 3.5-5.0 kg resin could be tapped from one tree of Pinus roxburghii.

Pinus roxburghii had the fourth highest position in term of total growing stock and identified as the major forest type in Nepalese forest classification (DFRS, 1999). Resin collection only could be a viable source of income for the local people and revenue for the nation and CFUGs (Jackson, 1996; Kanel, 2004) however it needs carefully regulated tapping intensity. 


\section{Socially harmonious}

Community based forest management practices are seen exemplary to bring the positive changes in communities except few cases. The equitable distribution of benefits of CFUG fund is at least 35\% allocation of total CFUG fund (provision made by legislative provision from the community forestry guideline, 2009) has been implicated to ensure the well-organized social inclusion exercises. The mandatory representation of women, and disadvantaged groups (DAGs) in executive committee is another way to ensure the inclusive decision making in CFUG. Another vital obligatory provision of employing womans and DAGs household in resin collection scheme and employ the local supervisor are found sustainable practices in resin collection and skill development trainings provided before the resin collection helps to transfer the new technology and innovation for local people to get employment in the future days. Still, the enabling environment is further required to control the eliteness and participatory monitoring tool.

\section{Institutional robustness}

There has already been documented the success stories and evidences of re-inventing forestry agencies in community forest regime (Kanel \& Acharya, 2008) with the growing number of CFUG formation. CFUGs has established as robust local organization to manage multi-stakeholder coordination and cooperation and FECOFUN has been available in dealing for the advocacy issues of CFUGs on policy level. Since pine resin collection work is established as lucrative business in mountain CF of Nepal, it could be highly supportive to enhance green business. As autonomous body, CFUG operates its activities beyond the boundary of forest for example some CFUG's contribution to the community development works and establishing micro-cooperatives and micro-enterprises. While dealing with resin collection concessions, the institutional set up could be strenghthened.

\section{Economically viable enterprise}

Although most of the trade agreement has still been made without complete and updated market information, the proportion of revenue achieved by the CFUG is again the primary source of income in community fund and indirectly government also get the revenue. Employment in the collection work (unskilled worker, skilled worker, local supervisor) is another vital source to earn by lcoal people. Subedi (2010) revealed that per season (8 months because one cycle of resin collection work took 8 months), one unskilled labour could earn $\$ 400$, which is quite good from the economic incentive point of view that they can continue their extra earnings (cultivation of regular agriculutre crops and cattle rearing etc). The local Community Based Organisations(CBOs), and clubs charged some levy to concessionaire as kind support for community development. The physical assets were developed side by side to make access to the forest depot of resin collection.

\section{Legal reforms}

Major acts and regulations including Forest Act 1993, Forest Regulation 1995, Environmental Protection Act 1995 and Environment Protection Regulation 1996 are established as key 
legal instruments to ensure environmental congruence from any type of forest products extraction. Particularly EIA/IEE is key policy envisioned to ensure most of the extractive work and subsequent compensation in forest areas in sustainable way. Annual Allowable Harvest (AAH) is mandatory parameter in the CF operational (management) Plan and it states that annual allowable collection of resin is scientifically calculated by using data from systematic sampling of existing forest stock. The role of CFUG is vital to ensure all dimensions of sustainability because of its autonomous status according to prevailing forest law 1993 and able to get multi-sector support from CBO, INGO/NGO apart from DFO is highly demonstrable.

\section{Conclusion}

It can be concluded that there is not any discouraging business environment for sustainable collection and trade of pine resin. Resin collection should be the safety nets for poor people in mid-hills of Nepal but the participatory process should be opted to be enacted. Rule of law and transparency in collective action are found crucial to maintain the good governance in collective resource management regime. Low price of crude resin per unit weight, long time period of tapping, extraction from overstorey large trees in large patch of forest are major attributes in pine resin collection, that's why rather than individual earning, it supports by indirect impacts by concessionaire and derived impacts through CFUG fund. The normal rotation age of pine was noted 60 years in Nepal and resin tapping can be done for 20 years if it done properly, it does mean, some sort of silvicultural intervention would be needed in pine stand to commercialize in mega scale. Various steps of transformation have to be bridged to secure the poor's welfare by NTFPs even sustainable commercialization is practiced in CFUGs. Based on available data, collection and trade of resin is not fully operated as stated in bilateral agreement between forest owner and concessionaire, so considering to the market demand and socio-economic status of users, the nationwide awareness and enterprising assignment could be promoted by governing bodies without undermining the ecological balance, social and economic well-being of people.

\section{References}

Arnold a, J. M., \& Pérez, M. R. 2001. Can non-timber forest products match tropical forest conservation and development objectives? Ecological Economics, 39 (3), 437-447.

Belcher, B., Perez, M. E. and Achdiawan, R. 2005. Global patterns and trends in use and Management of Commercial NTFPs: Implications for livelihood and conservation. World Development , 33 (9), 1435-1452.

Belcher, C. M. 2003. What isn't NTFP? International Forestry Review , 5 (2), 161-168.

Chhetri, R. and Gotame, B. 2010. Employment Generation and Economic up scaling from Collection and Trade of Yarsagumba (Ophiocordyceps sinensis) (Berk.) in Nepal. 
Procedding: Forest-People Interaction (pp. 13-19). Pokhara, Nepal: UMB/NUFU Project, Institiute of Forestry, Pokhara, Nepal.

Coppen, J. J. and Hone, G. A. 1995. Gum naval stores: Turpentine and rosin from pine Organization Of The United Nations, Rome, www. Gum naval stores/Turpentine and rosin from pine resin/ html.

Edmonds, V. C. 2002. Government-initiated community resource. Journal of Development Economics , 68, 89-115.

GoN. 1995. Forest Law and Forest Regulation. Government Of Nepal.

GoN. 2004. Non-Timber Forest Product Policy. GoN.

GoN/MoFSC. 2002. Nepal Biodiversity Strategy. kathmandu: Ministry of Forest and Soil Conservation, Governent of Nepal.

GRTL. 2007. Progress Report of Environmental Impact Assessment (EIA) Implementation: related to resin tapping for the Rolpa, Salyan, Puythan and Dang Districts. Ganpati Rosin and Turpentine Industries pvt.Ltd, Kapilvastu, Nepal.

Guariguata, M. R., Cronkleton, P., Shanley, P. and Taylor, P. L. 2008. The compatibility of timber and non-timber forest product extraction and management. Forest Ecology and Management , 256, 1477-1481.

Gyawali, D. 2010. Situation analysis of forest products collection, distribution and trade (In Nepali) In Hamro ban. Kathmandu, Nepal: Department of Forest, Nepal.

Heinen, A. S.-A. 2006. Emerging policy issues on Non-timber forest products in Nepal. HIMALAYA, XXVI (1-2), 51-53.

Jackson, J. K. 1996. Mannaul of Afforestation in Nepal: Vol 2. Department of Forest Research and Survey/Ministry of Forest and Soil Conservation/Government of Nepal.

Kanel, K. R. 2004. 25 years of community forestry in Nepal: Contribution to Millenium Development Goal. In K. R. Kanel, \& e. al (Ed.), 25 years of Community Forestry in Nepal (pp. 1-16). Community Forestry Division/Department of Forest/Government of Nepal.

Kanel, K. R. 2007. Economic Impacts of Forest Policy Changes: A Perspective from Nepal. The Initiation , 1, 036-042. 
Kanel, K. R. and Acharya, D. P. 2008. Re-inventing forestry agencies: Institutional innovation to support community forestry in Nepal. In Re-inventing forestry agencies: Experiences of

Institutional restructuring in Asia and pacific (pp. 133-156). Asia Pacific Forestry Commision/Food and Agricultural Oraganization,.

Marshell, A., Newton, A. C., \& Schreckenberg, K. 2003. Commercialisation of non-timber forest products: first steps in analysing the factors influencing success. International Forestry Review , 5 (3), 128-137.

Mehata, T. 1981. A hand book of Forest Utilization. Periodical Ezpert Book Agency, Delhi, India.

MoFSC/GoN. 2007. Resin Collection Guideline. Ministry of Forest and Soil Conservation/ Government of Nepal.

Neumann, R. P. and Hirsch, E. 2000. Commercialization of Non-Timber Forest Products: Review and Analysis of Research. Center for International Forestry Research (CIFOR), Bogor, Indonesia \& FAO.

Nurse, M., Pokharel, B., Khatri, D. B. and Paudel, D. 2005. Rural Entrepreneur Development: A Pro-poor Approach to enterprise development through Community Forestry. In K. R.

Kanel, \& et al (Ed.), 25 Years of Community Forestry: Contribution to the Millenium Development Goals. Department of Forest/Ministery of Forest and Soil Conservation/ Government of Nepal.

Ojha, H. R. 2000. Current policy issues in NTFP development in Nepal. Kathmandu, Nepal: Asia Network for Small-scale Bio-resources (ANSAB).

Paudyal, D. 2009. Sustainable resin tapping in Nepal: Challenges and Oppertunities (A case from Salyan District). The Initiation, 2 (1).

Pimental, D., Wilson, C., McCullum, C., Huang, R., Dwen, P., Flack, J., et al. 1997. Economics and Environmental Benefits of Biodiversity. BioScience, 47 (11), 747-757.

Shanley, P., Pierce, A., Laird, S. and Guillen, A. (Eds.). 2002. Tapping the green market, Certification andmanagement of Non-timber forest products. UK: People and Conservation Series, Earthscan Publication Ltd. 
Sharma, U. R. 2007. Medicinal and Aromatic Plants: A growing commercial setors of Nepal. The Initiation , 1 (1), 4-8.

Subedi, L. P. 2010. Employment opportunity from Resin Tapping in Nepal. Ganapati Rosin and Turpentine Pvt. Ltd, Nepal on http://www.forestrynepal.org/images/ Employment\%20opportunity\%20from\%20Resin\%20T mapping \%20in\%20Nepal. pdf. (accessed on 02/02/2012) .

Wunder, S. 2001. Poverty Alleviation and Tropical Forests- What scope for synergies? World Development , 29 (11), 1817-1833. 